\title{
STUDENT ACHIEVEMENT IN THE UNIVERSITY ENTRANCE EXAMINATION AND THE EFFECTS OF PREPARATION CLASSES - A CASE STUDY OF CIVIL ENGINEERING STUDENTS
}

\author{
Ljubiša Preradović, Sandra Kosić-Jeremić
}

Preliminary notes

This paper presents the achievement in the university entrance examination of secondary school graduates who applied for matriculation in The Faculty of Architecture, Civil Engineering and Geodesy, course Civil Engineering, Banja Luka University, in June 2012. The applicant achievement in the mathematics and physics parts of the examination is analysed with regard to attendance in the preparation courses and academic achievement in secondary school. Based on the findings, the authors make certain conclusions and recommendations intended to help improve the quality of secondary education, especially the teaching of mathematics and physics, through syllabus modification. They also recommended making a comprehensive analysis of university student achievement relative to the type of secondary school completed, and holding thematic meetings with teachers in technical/vocational secondary schools, in order to point to the specific topics or units that students find exceptionally challenging to deal with in university.

Keywords: achievement analysis; preparation classes; software support; university entrance examination

\section{Efekti pripremne nastave i analiza uspjeha studenata u polaganju kvalifikacijskog ispita - prikaz slučaja studenata građevinarstva}

Prethodno priopćenje U ovom radu predstavljeni su rezultati kandidata koji su konkurirali na Arhitektonsko-građevinsko-geodetskom fakultetu Univerziteta u Banjoj Luci za upis na studijski program Građevinarstvo tijekom lipnja 2012. Analizirana je uspješnost kandidata iz predmeta matematika i fizika koje su kandidati osvojili tijekom kvalifikacijskog ispita u ovisnosti o pohađanju pripremne nastave, kao i značajnost uspjeha tijekom srednjoškolskog obrazovanja i završenoj srednjoj školi. Na osnovu dobivenih rezultata izvedeni su određeni zaključci i dane preporuke autora za poboljšanje kvalitete srednjoškolske nastave, posebice nastavnih sadržaja iz matematike i fizike. Također je preporučeno da se napravi detaljna analiza uspješnosti studenata na fakultetu prema završenim srednjim školama, kao i da se organiziraju tematski sastanci s nastavnicima koji izvode nastavu u strukovnim srednjim školama kako bi se ukazalo na posebne nastavne cjeline s kojima su studenti imali probleme tijekom studiranja.

Ključne riječi: analiza uspješnosti; kvalifikacioni ispiti; pripremna nastava; softverska podrška

\section{Introduction}

Educating civil engineering and architecture technicians in Banja Luka first began in 1939, followed by surveying technicians in 1978 [1].

The Faculty of Architecture, Civil Engineering and Geodesy (AGGF) in Banja Luka offers three study programmes: Architecture, Civil Engineering and Geodesy. By the beginning of the academic year 2012/13, AGGF had enrolled 3520 students, of which 699 had graduated following the old curriculum, and 282 following the new (Bologna) curriculum (240 ECTS). Seven students had completed a master's course, fifteen had earned a master's degree following the old curriculum (4 or 5+2 years), and twelve had earned a doctoral degree.

By the beginning of the academic year 2012/13, a total of 295 students had graduated from the Department of Civil Engineering following the old curriculum (10 semesters), and 46 following the new (Bologna) course.

Forty graduates of four-year secondary schools matriculated in each of the three courses in the academic year 2012/13 (a total of 120). The number of applicants was 229 ( 81 for the Architecture Course, 48 for the Civil Engineering Course, and 100 for the Geodesy Course). Most of the applicants came from Bosnia and Herzegovina (223), 3 were from Serbia, 1 from Croatia, and 1 from Montenegro.

Since 2007, AGGF has held preparation classes in the subjects tested in the entrance examination (mathematics and physics), which take place over two weeks in June (20 classes per subject). The applicants may win a maximum of 50 points based on their secondary school achievement (GPA multiplied by 10). They may also win up to 50 points based on their achievement in the entrance examination: 35 for the mathematics part (7 problems worth 5 points each) and 15 for the physics part (3 problems worth 5 points each). The minimum achievement required for an applicant to pass the examination is 15 points, provided he or she scores a minimum of $20 \%$ in each of the parts ( 7 points in the mathematics test and 3 points in the physics test). All the applicants who passed the entrance examination were admitted. Admission to the Faculty of Civil Engineering of Mostar University [2] is made exclusively based on the applicants' secondary school achievement:

a) For the first two years of secondary school, the GPA, mathematics and physics grades are taken into account; for the junior year, it is the GPA and the mathematics grade; for the senior year, it is the GPA, the graduation exam grade and the mathematics grade. The grades are rounded off to one decimal place.

b) The rounded GPAs are added up, multiplied by one hundred and divided by four.

c) The result represents the number of points awarded to the applicant.

Point calculation is possible on-line. A minimum of 300 points is required for matriculation. The pre-specified numbers of applicants matriculate relative to their rank according to the above selection procedure. 
There is no matriculation examination in the Republic of Croatia. Students are admitted based on their achievement in the State Secondary School Graduation Exam (taken by all students graduating from secondary schools, both academic and vocational). Students may take Examination A (more difficult, higher total score) or Examination B. After taking the State Examination (compulsory subjects: mathematics, Croatian, English; elective subject: physics), a rank list is made. The Faculties of Civil Engineering of the Universities of Zagreb, Osijek and Split award $40 \%$ and $60 \%$ of the points based on the applicant's secondary school and State Examination achievement respectively [3, 4, 5], while the Faculty of Civil Engineering of Rijeka University awards $40 \%$ for each, allowing the applicants to win an additional $20 \%$ by taking a test in IT, chemistry or physics [6].

When it comes to the Faculty of Civil Engineering of Belgrade University, a prospective student may win a maximum of $40 \%$ of points based on his or her secondary school GPA, and the remaining $60 \%$ are awarded based on the score won in a mathematics entrance test [7]. Rules allow applicants to the Faculty of Civil Engineering and Architecture of Niš University to win $60 \%$ of the total points by taking a mathematics test, and another $30 \%$ based on success in physics or engineering mechanics test [8].

The University of Podgorica has specific requirements with regards to the type of secondary school that may allow progression to any individual department or faculty. The enrolment rank list is made based on the applicants' secondary school GPA, secondary school graduation exam achievement, mathematics and physics grades in the junior and senior years of secondary school, and achievement in an additional examination [9].

\section{Subject matter and methods}

This paper presents the success rates of secondary school graduates who applied for enrolment in the course
Civil Engineering relative to two criteria, secondary school achievement and entrance examination achievement, with a focus on the relevance of attendance in the preparation classes held in university.

The obtained results were processed and presented using descriptive statistics, namely, the Mann-Whitney U test and the Yates' chi-squared test, and the SPSS statistical analysis software package (originally: Statistical Product and Service Solutions).

\section{Analysis of secondary school achievement and university entrance examination scores}

No in-depth analysis of the effects of the preparation courses held at the Faculty of Architecture, Civil Engineering and Geodesy and the University of Banja Luka has been carried out to date. Only individual indicators have been observed, e.g., secondary school breakdown according to type with regard to matriculating applicants, secondary school GPA, and achievement in the matriculation examination [10]. This study was conducted on a sample of 48 students who applied for admission to the Department of Civil Engineering in the academic year 2012/13.

Tab. 1 shows the applicants' achievement in the entrance examination relative to the type of secondary school completed and gender.

There were fewer female applicants and they won higher scores: 13 out of 16 applicants had passing scores $(81,25 \%)$, compared to 32 male applicants, of whom 17 passed the exam $(53,13 \%)$.

Half of the applicants (24) came from Banja Luka, and the majority of them (20) were graduates of the Banja Luka Civil Engineering Secondary School (of whom 12 passed the examination and 8 failed); two applicants came from the Banja Luka Gymnasium and both passed the exam, along with one successful applicant from the Banja Luka Roman Catholic Education Centre; lastly, an applicant from the Banja Luka Secondary School of Electrical Engineering failed to win a passing score.

Table 1 Achievement in the university entrance examination relative to the type of secondary school completed and the applicant gender

\begin{tabular}{|c|c|c|c|c|c|}
\hline \multirow{2}{*}{\multicolumn{3}{|c|}{ Pass achievement in the entrance examination }} & \multicolumn{2}{|c|}{ Gender } & \multirow{2}{*}{ Total } \\
\hline & & & Female & Male & \\
\hline \multirow{5}{*}{ Yes } & \multirow{4}{*}{ Secondary school } & Gymnasium (academic) & 4 & 4 & 8 \\
\hline & & Civil Engineering Secondary & 6 & 8 & 14 \\
\hline & & Other technical schools & 0 & 1 & 1 \\
\hline & & Other schools & 3 & 4 & 7 \\
\hline & \multicolumn{2}{|r|}{ Subtotal } & 13 & 17 & 30 \\
\hline \multirow{5}{*}{ No } & \multirow{4}{*}{ Secondary school } & Gymnasium (academic) & 0 & 2 & 2 \\
\hline & & Civil Engineering Secondary & 1 & 9 & 10 \\
\hline & & Other technical schools & 0 & 3 & 3 \\
\hline & & Other schools & 2 & 1 & 3 \\
\hline & \multicolumn{2}{|r|}{ Subtotal } & 3 & 15 & 18 \\
\hline \multirow{5}{*}{ Total } & \multirow{4}{*}{ Secondary school } & Gymnasium (academic) & 4 & 6 & 10 \\
\hline & & Civil Engineering Secondary & 7 & 17 & 24 \\
\hline & & Other technical schools & 0 & 4 & 4 \\
\hline & & Other schools & 5 & 5 & 10 \\
\hline & & Total & 16 & 32 & 48 \\
\hline
\end{tabular}

Only 1 out of 18 applicants with an excellent GPA (a graduate of the Mrkonjić Grad Gymnasium) failed the entrance examination (Tab. 2).
Thirty-one points was the lowest score awarded based on the secondary school GPA of an applicant who passed the entrance examination, as opposed to 47 points as the highest GPA-based score awarded to a failing applicant, 
which points to the significance of the secondary school completed.

The average secondary school GPA of passing applicants was 43,69, and of the failing it was 35,24 (Tab. 3). The Mann-Whitney U test [12] reveals high statistical significance of secondary school GPA of the passing applicants $(M d=45,32 ; N=30)$ and of the failing applicants $(M d=35,53 ; N=18), U=87,000, z=-3,898$, $p=0,000, r=0,563)$.

Table 2 Achievement in the university entrance examination relative to

\begin{tabular}{|c|c|c|c|c|}
\hline \multirow{2}{*}{\multicolumn{2}{|c|}{ GPA }} & \multicolumn{2}{|c|}{$\begin{array}{l}\text { Passing score in entrance } \\
\text { examination }\end{array}$} & \multirow[t]{2}{*}{ Total } \\
\hline & & Yes & No & \\
\hline \multirow{3}{*}{ Good } & $N$ & 3 & 9 & 12 \\
\hline & & $25,0 \%$ & $75,0 \%$ & $100,0 \%$ \\
\hline & & $10,0 \%$ & $50,0 \%$ & $25,0 \%$ \\
\hline \multirow{3}{*}{ Very good } & $N$ & 10 & 8 & 18 \\
\hline & & $55,6 \%$ & $44,4 \%$ & $100,0 \%$ \\
\hline & & $33,3 \%$ & $44,4 \%$ & $37,5 \%$ \\
\hline \multirow{3}{*}{ Excellent } & $N$ & 17 & 1 & 18 \\
\hline & & $94,4 \%$ & $5,6 \%$ & $100,0 \%$ \\
\hline & & $56,7 \%$ & $5,6 \%$ & $37,5 \%$ \\
\hline \multirow{3}{*}{ Total } & $N$ & 30 & 18 & 48 \\
\hline & & $62,5 \%$ & $37,5 \%$ & $100,0 \%$ \\
\hline & & $62,5 \%$ & $37,5 \%$ & $100,0 \%$ \\
\hline
\end{tabular}

Table 3 Secondary school GPA

\begin{tabular}{|c|c|c|c|c|c|c|c|}
\hline Enrolled & $\mathrm{N}$ & Min. & Max. & Range & Median & Mean & Std. Dev. \\
\hline Yes & 30 & 31 & 50 & 19 & 45,32 & 43,69 & 5,618 \\
\hline No & 18 & 26 & 47 & 21 & 35,53 & 35,24 & 6,019 \\
\hline Total & 48 & 26 & 50 & 24 & 40,73 & 40,52 & 7,047 \\
\hline
\end{tabular}

The lowest score achieved in the entrance examination was 15 , and the highest 49 . The highest score won in the entrance examination by a failing applicant was 19. The average score of the passing applicants was 30,2 , and that of the failing applicants 6778 (Tab. 4). The Mann-Whitney $U$ test [11] shows high statistical significance of the entrance examination achievement of the passing applicants $(M d=28,25 ; N=30)$ and of the failing applicants $(M d=6,50 ; N=18), U=8,000, \mathrm{z}=$ $-5,582, p=0,000, r=0,806)$.

Table 4 Entrance examination - scores

\begin{tabular}{|c|c|c|c|c|c|c|c|}
\hline PKI & $\mathrm{N}$ & Min. & Max. & Range & Median & Mean & Std. Dev. \\
\hline Yes & 30 & 15,0 & 49,0 & 34,0 & 28,250 & 30,200 & 11,4196 \\
\hline No & 18 & 0,0 & 19,0 & 19,0 & 6,500 & 6,778 & 5,2782 \\
\hline Total & 48 & 0,0 & 49,0 & 49,0 & 18,250 & 21,417 & 14,8948 \\
\hline
\end{tabular}

Table 5 Total points

\begin{tabular}{|c|c|c|c|c|c|c|c|}
\hline Enrolled & $\mathrm{N}$ & Min. & Max. & Range & Median & Mean & Std. Dev. \\
\hline Yes & 30 & 49.4 & 97.6 & 48.2 & 74.980 & 73.891 & 14.8417 \\
\hline No & 18 & 29.2 & 60.2 & 31.0 & 42.260 & 42.021 & 9.8036 \\
\hline Total & 48 & 29.2 & 97.6 & 68.5 & 59.270 & 61.940 & 20.3422 \\
\hline
\end{tabular}

The lowest total points won by an applicant based on the secondary school GPA and the entrance examination score was 49,4, and the highest 97,6. The highest total points won by an applicant based on the secondary school GPA who failed the entrance examination was 60,2, and the lowest 29,2. The matriculating applicants had an average score of 73,89, and for those who failed the entrance examination it was 42,02 (Tab. 5). The MannWhitney $U$ test [12] pointed to high statistical significance in terms of the total points won by the matriculating applicants $(M d=74,98 ; N=30)$ and the failing ones $(M d$
$=42,26 ; N=18), U=17,000, z=-5,388, p=0,000, r=$ $0,777)$.

\section{Analysis of the mathematics test achievement}

The mathematics preparation course mainly revised the content taught in the first two years of secondary school, which are tested in the entrance examination.

The mathematics preparation class (MM-PN) was attended by $26(54,17 \%)$ applicants; on average, they achieved a higher score in the exam $(15,96)$, compared to the applicants who did not take the class $(22$, or $45,83 \%)$, whose average score was 12,91 (Tab. 6). The MannWhitney U test [12] did not show considerable statistical significance of the mathematics test achievement of the applicants who took the mathematics preparation class $(M d=14,50 ; N=26)$ and of those who did not $(M d=$ $11,00 ; N=22), U=240,500, z=-0,943, p=0,346, r=$ $0,136)$.

Thirty-four (70,8 \%) applicants passed the mathematics part of the entrance exam. Nineteen out of 26 applicants who took the preparation class won a passing score in the examination (Tab. 7).

Table 6 Applicant achievement in the mathematics part of the entrance examination relative to attendance in the preparation class

\begin{tabular}{|c|c|c|c|c|c|c|c|}
\hline MM - PN & N & Min. & Max. & Range & Median & Mean & Std. Dev. \\
\hline Yes & 26 & 0 & 35 & 35 & 14,50 & 15,96 & 11,123 \\
\hline No & 22 & 0 & 34 & 34 & 11,00 & 12,91 & 9,802 \\
\hline Total & 48 & 0 & 35 & 35 & 12,00 & 14,56 & 10,541 \\
\hline
\end{tabular}

Yates' chi-squared test does not indicate statistical significance of the correlation between the entrance examination achievement and attendance in the mathematics preparation class, $\chi^{2}(1, n=48)=0,003$; $p=$ 0,$958 ; f i=0,054$.

Table 7 Applicant achievement in the mathematics part of the entrance examination relative to attendance in the preparation class

\begin{tabular}{|c|c|c|c|c|}
\hline \multicolumn{2}{|c|}{ MM - PN } & \multicolumn{2}{|c|}{$\begin{array}{c}\text { Mathematics test - passing } \\
\text { score }\end{array}$} & \multirow{2}{*}{ Total } \\
\cline { 3 - 5 } & & Yes & No & \\
\hline \multirow{3}{*}{ Yes } & $\mathrm{N}$ & 19 & 7 & 26 \\
\cline { 3 - 6 } & & $73,1 \%$ & $26,9 \%$ & $100,0 \%$ \\
\cline { 3 - 6 } & & $55,9 \%$ & $50,0 \%$ & $54,2 \%$ \\
\hline \multirow{3}{*}{ No } & $\mathrm{N}$ & 15 & 7 & 22 \\
\cline { 3 - 6 } & & $68,2 \%$ & $31,8 \%$ & $100,0 \%$ \\
\cline { 3 - 6 } & & $44,1 \%$ & $50,0 \%$ & $45,8 \%$ \\
\hline \multirow{3}{*}{ Total } & $\mathrm{N}$ & 34 & 14 & 48 \\
\cline { 3 - 6 } & & $70,8 \%$ & $29,2 \%$ & $100,0 \%$ \\
\cline { 3 - 5 } & & $100,0 \%$ & $100,0 \%$ & $100,0 \%$ \\
\hline
\end{tabular}

Tab. 8 presents the number of applicants who passed/failed the mathematics entrance test relative to attendance in the preparation class and the type of secondary school completed.

Fig. 1 shows applicant achievement in the mathematics test relative to secondary school GPA, attendance in the preparation class (MM - PN), and the passing score won in the entrance exam (PKI).

The applicants who took the mathematics preparation class scored higher in the entrance examination on average. All the applicants with an excellent secondary school GPA who took the preparation class passed the entrance examination (average score 26,71), whereas those who did not take the class but passed the entrance 
examination had an average score of 21,10 points. The applicants with an excellent secondary school GPA who neither took the preparation class nor passed the entrance examination won 10 points on average. The applicants with a very good secondary school GPA who took the preparation class won 18,63 points on average (passing applicants). The applicants who failed the entrance exam despite taking the preparation class had an average score identical to that of the applicants who enrolled without attending the preparation courses (nine applicants in each category). The average score in the mathematics test of the applicants who passed the entrance examination, had a very good secondary school GPA and took the preparation class was higher $(13,5)$ compared to that won by the applicants who had a good secondary school GPA and did not attend the preparation courses (12).

Table 8 The number of applicants who passed/failed the mathematics part of the entrance examination relative to attendance in the preparation class and the type of secondary school completed

\begin{tabular}{|c|c|c|c|}
\hline \multirow[t]{2}{*}{ Secondary school } & \multicolumn{2}{|c|}{$\begin{array}{l}\text { Mathematics test - passing } \\
\text { score (students who took the } \\
\text { preparation class) }\end{array}$} & \multirow[t]{2}{*}{ Total } \\
\hline & Yes & No & \\
\hline Gymnasium (academic) & $10(7)$ & $0(0)$ & $10(7)$ \\
\hline Civil Eng Secondary & $15(7)$ & $9(4)$ & $24(11)$ \\
\hline Other technical schools & $1(1)$ & $3(2)$ & $4(3)$ \\
\hline Other schools & $8(4)$ & $2(1)$ & $10(5)$ \\
\hline Total & $34(19)$ & $14(7)$ & $48(26)$ \\
\hline
\end{tabular}

Those applicants who failed the entrance examination, had a good secondary school GPA and attended the preparation class won 3,2 points on average, and those who did not take the class won 2,75 points on average.

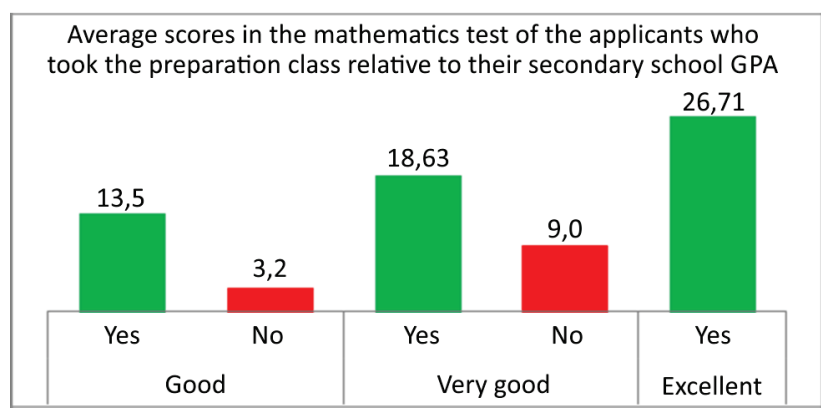

Average scores in the mathematics test of the applicants who did not teke the preparation class relative to their secondary school GPA

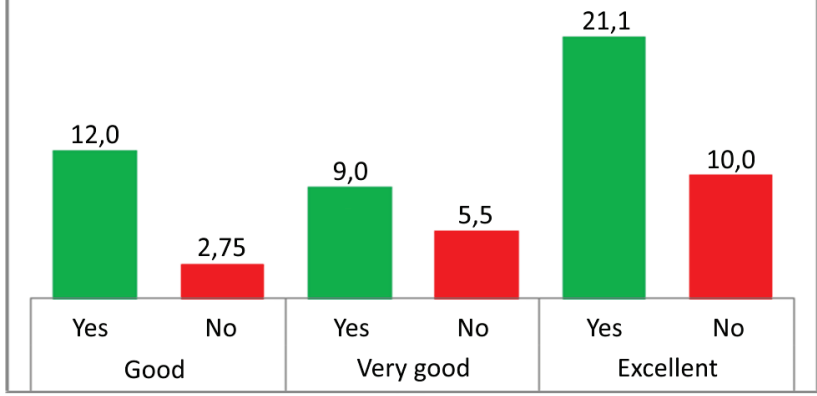

Figure 1 Average applicant achievement in the mathematics part of the entrance examination

Table 9 Applicant achievement in the mathematics part of the entrance examination relative to secondary school GPA and the type of secondary school completed

\begin{tabular}{|c|c|c|c|c|c|}
\hline \multirow{2}{*}{\multicolumn{3}{|c|}{ Secondary school GPA }} & \multicolumn{2}{|c|}{ Mathematics test - passing score } & \multirow{3}{*}{$\begin{array}{c}\text { Total } \\
1\end{array}$} \\
\hline & & & Yes & No & \\
\hline \multirow{5}{*}{ Good } & \multirow{4}{*}{ Secondary school } & Gymnasium (academic) & 1 & 0 & \\
\hline & & Civil Engineering Second & 1 & 7 & 8 \\
\hline & & Other technical schools & 0 & 2 & 2 \\
\hline & & Other schools & 1 & 0 & 1 \\
\hline & & Subtotal & 3 & 9 & 12 \\
\hline \multirow{5}{*}{ Very good } & \multirow{4}{*}{ Secondary school } & Gymnasium (academic) & 5 & 0 & 5 \\
\hline & & Civil Engineering Second & 5 & 2 & 7 \\
\hline & & Other technical schools & 0 & 1 & 1 \\
\hline & & Other schools & 3 & 2 & 5 \\
\hline & & Subtotal & 13 & 5 & 18 \\
\hline \multirow{5}{*}{ Excellent } & \multirow{4}{*}{ Secondary school } & Gymnasium (academic) & 4 & & 4 \\
\hline & & Civil Engineering Second & 9 & & 9 \\
\hline & & Other technical schools & 1 & & 1 \\
\hline & & Other schools & 4 & & 4 \\
\hline & & Subtotal & 18 & & 18 \\
\hline \multirow{5}{*}{ Total } & \multirow{4}{*}{ Secondary school } & Gymnasium (academic) & 10 & 0 & 10 \\
\hline & & Civil Engineering Second & 15 & 9 & 24 \\
\hline & & Other technical schools & 1 & 3 & 4 \\
\hline & & Other schools & 8 & 2 & 10 \\
\hline & & Total & 34 & 14 & 48 \\
\hline
\end{tabular}

An analysis of the impact of the applicant secondary school GPA and the type of secondary school completed on the achievement in the entrance examination reveals that all applicants with an excellent GPA from any type of school, along with all applicants from gymnasiums (academic secondary schools), passed the mathematics entrance test. The applicants from "other" technical schools with a good or a very good secondary school
GPA failed the entrance examination. Only one applicant from the Civil Engineering Secondary School with a good GPA won a passing score, along with 5 out of 7 applicants with a very good GPA (Tab. 9). 


\section{Analysis of the physics test achievement}

The physics preparation course (FZ - PN) was attended by $25(52,08 \%)$ applicants, and they also won a higher average score in the entrance examination $(8,70)$ compared to those who did not attend it (23, or $47,91 \%)$, who won 4,85 points on average (Tab. 10). The MannWhitney $U$ test [12] reveals statistical significance of the physics test achievement of the applicants who took the preparation class $(M d=10,00 ; N=25)$ and those who did $\operatorname{not}(M d=4.00 ; N=23), U=169,000, z=-2,454, p=$ $0,014, r=0,354)$.

Thirty-five $(72,9 \%)$ applicants passed the physics part of the entrance test. Out of 25 applicants who took the physics preparation class, 20 passed the entrance exam (Tab. 11).

Yates' chi-squared test does not show statistical significance of the connection between the entrance examination achievement and attendance in the physics preparation class, $\chi^{2}(1, n=48)=0,683, p=0,409, f i=$ 0,166 .

Table 10 Applicant achievement in the physics part of the entrance examination relative to attendance in the preparation class

\begin{tabular}{|c|c|c|c|c|c|c|c|}
\hline FZ - PN & N & Min. & Max. & Range & Median & Mean & Std. Dev. \\
\hline Yes & 25 & 0 & 15 & 15 & 10,00 & 8,70 & 5,464 \\
\hline No & 23 & 0 & 15 & 15 & 4,00 & 4,85 & 4,344 \\
\hline Total & 48 & 0 & 15 & 15 & 5,75 & 6,85 & 5,278 \\
\hline
\end{tabular}

Table 11 Applicant achievement in the physics part of the entrance examination relative to attendance in the preparation class

\begin{tabular}{|c|c|c|c|c|}
\hline \multirow{2}{*}{\multicolumn{2}{|c|}{$\mathrm{FZ}-\mathrm{PN}$}} & \multicolumn{2}{|c|}{ Physics test - passing score } & \multirow{2}{*}{ Total } \\
\hline & & Yes & No & \\
\hline \multirow{3}{*}{ Yes } & $\mathrm{N}$ & 20 & 5 & 25 \\
\hline & & $80,0 \%$ & $20,0 \%$ & $100,0 \%$ \\
\hline & & $57,1 \%$ & $38,5 \%$ & $52,1 \%$ \\
\hline \multirow{3}{*}{ No } & $\mathrm{N}$ & 15 & 8 & 23 \\
\hline & & $65,2 \%$ & $34,8 \%$ & $100,0 \%$ \\
\hline & & $42,9 \%$ & $61,5 \%$ & $47,9 \%$ \\
\hline \multirow{3}{*}{ Total } & $\mathrm{N}$ & 35 & 13 & 48 \\
\hline & & $72,9 \%$ & $27,1 \%$ & $100,0 \%$ \\
\hline & & $100,0 \%$ & $100,0 \%$ & $100,0 \%$ \\
\hline
\end{tabular}

Tab. 12 shows the number of applicants who passed/failed the physics entrance test relative to attendance in the preparation class and the type of secondary school completed.

Table 12 The number of applicants who passed/failed the physics part of the entrance examination relative to attendance in the preparation class and the type of secondary school completed

\begin{tabular}{|l|c|c|c|}
\hline \multirow{2}{*}{ Secondary school } & \multicolumn{2}{|c|}{$\begin{array}{c}\text { Physics test - passing score } \\
\text { (applicants who attended the } \\
\text { preparation class) }\end{array}$} & \multirow{2}{*}{ Total } \\
\cline { 2 - 3 } & $\mathrm{Da}$ & $\mathrm{Ne}$ & \\
\hline Gymnasium (academic) & $9(5)$ & $1(0)$ & $10(5)$ \\
\hline $\begin{array}{l}\text { Civil Engineering } \\
\text { Secondary }\end{array}$ & $18(9)$ & $6(2)$ & $24(11)$ \\
\hline Other technical schools & $1(1)$ & $3(2)$ & $4(3)$ \\
\hline Other schools Total & $7(5)$ & $3(1)$ & $10(6)$ \\
\hline \multicolumn{2}{|r|}{} & $13(7)$ & $48(25)$ \\
\hline
\end{tabular}

Fig. 2 shows applicant achievement in the physics part of the entrance examination relative to the applicant secondary school GPA, attendance in the preparation class (FZ-PN) and a passing score won in the entrance examination (PKI). The applicants who took the physics preparation class won a higher score in the entrance examination on average.

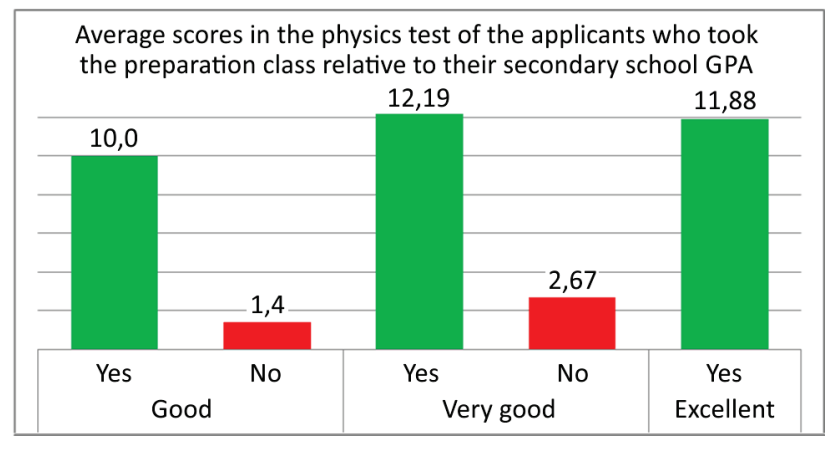

Average scores in the physics test of the applicants who did not take the preparation class relative to their secondary school GPA

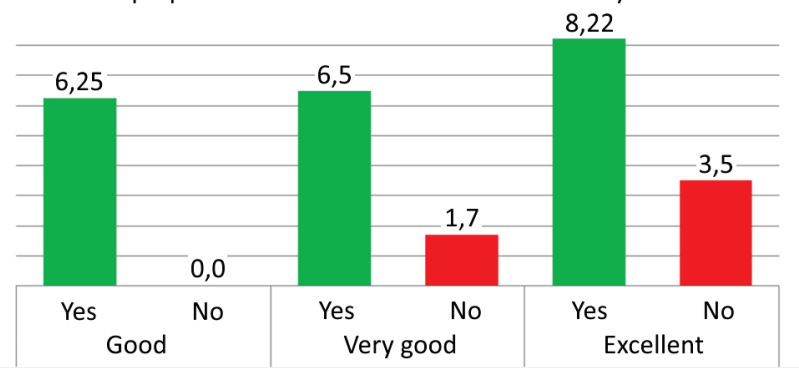

Figure 2 Average applicant achievement in the physics part of the entrance examination

All applicants with an excellent secondary school GPA who took the preparation class passed the physics test (average score achieved 11,88), while those applicants who did not take the preparation class but nonetheless passed the entrance examination won an average of 8,22 . The applicants with an excellent secondary school GPA who neither took the preparation class nor passed the entrance examination won an average of 3,5 points. The applicants who passed the entrance examination, had a very good secondary school GPA, and took the preparation class won an average of 12,19 points in the entrance examination (highest average score), i.e. 6.5 points (the applicants who did not take the preparation class), while the applicants who failed the entrance examination despite taking the preparation class won an average of 2,67 points, which was still higher than the score won by the applicants who did not take the preparation class $(1,7)$

The average score won in the physics test by the applicants who passed the entrance examination, had a good secondary school GPA and took the physics preparation class was higher (10) than the score won in the mathematics test by the applicants who had a good secondary school GPA and did not attend the mathematics preparation class $(6,25)$. The applicants who failed the entrance examination, had a good GPA and took the preparation class won an average of 1.4 points, whereas those who did not take the preparation class did not win any points.

An analysis of the impact of the applicant secondary school GPA and the type of secondary school completed on the achievement in the physics part of the entrance examination reveals that all applicants with an excellent GPA from any type of school passed the physics entrance test. The applicants who graduated from "other" technical 
schools with a good or very good GPA failed the entrance examination. Only 2 out of 8 applicants from the Civil Engineering Secondary School with a good GPA passed the entrance examination, whereas all 7 applicants with a very good GPA won a pass score in the exam (Tab. 13).

Table 13 Applicant achievements in the physics part of the entrance examination relative to secondary school GPA and the type of secondary school completed

\begin{tabular}{|c|c|c|c|c|c|}
\hline \multirow{2}{*}{\multicolumn{3}{|c|}{ Secondary school GPA }} & \multicolumn{2}{|c|}{ Physics test - passing score } & \multirow{2}{*}{ Total } \\
\hline & & & Yes & No & \\
\hline \multirow{5}{*}{ Good } & \multirow{4}{*}{ Secondary school } & Gymnasium (academic) & 1 & 0 & 1 \\
\hline & & Civil Engineering Secondary & 2 & 6 & 8 \\
\hline & & Other technical schools & 0 & 2 & 2 \\
\hline & & Other schools & 1 & 0 & 1 \\
\hline & & Subtotal & 4 & 8 & 12 \\
\hline \multirow{5}{*}{ Very good } & \multirow{4}{*}{ Secondary school } & Gymnasium (academic) & 4 & 1 & 5 \\
\hline & & Civil Engineering Secondary & 7 & 0 & 7 \\
\hline & & Other technical schools & 0 & 1 & 1 \\
\hline & & Other schools & 2 & 3 & 5 \\
\hline & & Subtotal & 13 & 5 & 18 \\
\hline \multirow{5}{*}{ Excellent } & \multirow{4}{*}{ Secondary school } & Gymnasium (academic) & 4 & & 4 \\
\hline & & Civil Engineering Secondary & 9 & & 9 \\
\hline & & Other technical schools & 1 & & 1 \\
\hline & & Other schools & 4 & & 4 \\
\hline & & Subtotal & 18 & & 18 \\
\hline \multirow{5}{*}{ Total } & \multirow{4}{*}{ Secondary school } & Gymnasium (academic) & 9 & 1 & 10 \\
\hline & & Civil Engineering Secondary & 18 & 6 & 24 \\
\hline & & Other technical schools & 1 & 3 & 4 \\
\hline & & Other schools & 7 & 3 & 10 \\
\hline & & Total & 35 & 13 & 48 \\
\hline
\end{tabular}

\section{Discussion and conclusion}

This paper presents the success rates of the secondary school graduates who applied for matriculation in the Faculty of Architecture, Civil Engineering and Geodesy of Banja Luka University, Civil Engineering Bachelor Course, in June 2012, based on their secondary school GPA and relative to the type of school completed, with a focus on the effects of the preparation classes held in university. All the applicants with an excellent secondary school GPA passed both the mathematics and physics parts of the entrance examination. One applicant who graduated from a gymnasium (academic secondary school) with a very good GPA failed the examination (the physics part), and two graduates of the Civil Engineering Secondary School failed the mathematics entrance test. All applicants who graduated from a gymnasium with a good GPA passed both parts of the exam, but only 2, i.e. 1 out of 8 applicants from the Civil Engineering Secondary School passed the physics part and the mathematics part of the exam respectively.

There is no statistical significance of the interdependence of the entrance test passing scores and attendance in the preparation courses, either for the mathematics section $(p=0,958)$, or the physics section ( $p$ $=0,409$ ).

A comparison of the achievement in the mathematics part of the exam of the applicants who attended the preparation class with that of those who did not does not yield statistical significance $(p=0,346)$, unlike the physics test $(p=0,014)$.

Observing the achievement of the total of 100 candidates who competed for matriculation in the Geodesy course the same year, we obtained these results. Based on two parameters, the passing score in the entrance examination and attendance in the mathematics preparation classes, the statistical significance $p=0,024$ was obtained in regard to the achievement in the entrance examination. Namely, the candidates who took the mathematics preparation course were more successful at solving the problems and had a better score in the entrance examination. Also, by comparison with the other candidates, gymnasium graduates had the highest average score in the test, along with the greatest average number of correctly solved problems [12].

However, if the overall candidate achievement in the entrance examination is observed, the general conclusion is we cannot be completely satisfied. Namely, out of the total of 48 candidates competing for admission to the course Civil Engineering, only 30 passed the entrance examination, along with 43 out of 100 who competed for the Geodesy course. The minimum score required for the passing score was $30 \%$ of the test.

We believe low achievement in the entrance examination and secondary school are the main reasons for the students' inability to pass their examinations during the studies and for their failure to acquire the mathematics and physics subject matter taught in the technical courses. This has also been proven by studies $[13,14,15,16]$, with students unable to demonstrate sufficient knowledge of mathematics or apply it in dealing with specialised subjects.

It would be necessary to broaden the scope of this analysis to some other aspects (e.g. computer skills and literacy of applicants) [17] and their impact on the passing rates, including student satisfaction with the reform of higher education in engineering departments [19] and analysis of the education process according to the old and new (Bologna) system of study.

It is necessary to examine the secondary school mathematics and physics syllabi and point to the content 
that is currently insufficiently covered. This analysis should cover the content taught in both academic and technical secondary schools, and the preparation classes should be readjusted to focus specifically on those units insufficiently taught in secondary school. It would be best to offer preparation classes over a period of time longer than currently, in order for the applicants to have sufficient time to practice the content that is not given enough space in school. A detailed analysis should be carried out of university student achievement according to the type of secondary school completed and thematic gatherings held with teachers working in technical, i.e. vocational schools to point to the particular content or units the university students find particularly challenging.

This analysis should make use of both standard and advanced techniques (e.g. data mining) to help identify causes and effects over relatively long periods of time. One of the analysis outcomes should be the revision of secondary school mathematics and physics syllabi. It is advisable to look more closely into the effects of the A and B secondary school graduation exams taken compulsorily in the Republic of Croatia in light of subsequent achievement of students enrolled in engineering courses, relative to the previously taken university entrance examinations.

Also, it would be useful for technical departments that do not currently offer preparation classes to introduce an obligatory mathematics preparation course or a course in basic mathematics at the beginning of the academic year, for the purpose of revision of secondary school mathematics subject matter, essential for successfully attending and mastering the mathematics modules taught in technical/engineering departments.

\section{References}

[1] http://www.gfos.unios.hr/portal/index.php/upisi opcenito.html. (11.12.2012).

[2] http://www.gfmo.ba/vodic_GF.pdf (23.01.2013).

[3] http://www.grad.unizg.hr/zavodi/zajednicke_sluzbe/ studentska_referada/upisi/preddiplomski1. (26.01.2013).

[4] http://www.gfos.unios.hr/portal/index.php/ upisi/opcenito.html. (26.01.2013)

[5] http://www.gradst.hr/Ostalo/Upisi/Sveu\%C4\%8Dili\%C5\% A1nistudijgra $\% \mathrm{C} 4 \% 91$ evinarstva/Preddiplomskisveu $\% \mathrm{C} 4$ \%8Dili\%C5\%A1nistudij/tabid/1174/Default.aspx. (26.01.2013).

[6] http://arhiva.gradri.hr/upisi/docs/2013-0606/Brosura_za_upise_2013_2014.pdf. (16.06.2014).

[7] http://www.grf.bg.ac.rs/upisise/pi. (10.06.2014).

[8] http://www.gaf.ni.ac.rs/_news/ info12/upis/ KONACNA\%20RANG\%20LISTA.pdf. (26.01.2013).

[9] http://www.ucg.ac.me/zakti/ Pravilnik\%20o\%20upisu\%20preciscen\%20tekst.pdf. (26.06.2013).

[10] http://unibl.org/uni/sajt/doc/File/dokumenti/ SAMOEVALUACIJA\%2029_03_2011.pdf. (27.6.2013.).

[11] Preradović, Lj.; Đajić, V. Analitičko-statističke tehnike u savremenim istraživanjima. Arhitektonsko-građevinski fakultet, Banja Luka, 2011.

[12] Preradović, Lj. et al. Uticaj srednjoškolskog obrazovanja i pripremne nastave na uspjeh kandidata pri polaganju kvalifikacionog ispita na Arhitektonsko-građevinskom fakultetu Univerziteta u Banjaluci tokom 2012. godine. Arhitektonsko-građevinski fakultet, Banja Luka, 2013.
[13] Gill, P. Aspects of undergraduate engineering students' understanding of mathematics. // International Journal of Mathematical Education in Science and Technology. 30, 4(1999), pp. 557-563. DOI: 10.1080/002073999287824

[14] Kosić-Jeremić, S. Teaching mathematics at faculties of engineering in Bosnia and Herzegovina viewed through teaching and solving extremal problems - a case study. // IMVI Open Mathematical Education Notes. 2, 1(2012), pp. 39-50.

[15] Jackman, S.; Goldfinch, J.; Searl, J. The effectiveness of coursework assessment in mathematics service courses studies at two universities. // International Journal of Mathematical Education in Science and Technology. 32, 2(2001), pp. 175-187. DOI: 10.1080/002073901300037627

[16] Britton, S. Are students able to transfer mathematical knowledge?, http://www.math.uoc.gr/ ictm2/ Proceedings/pap267.pdf . (14.10.2012).

[17] Kozina, G.; Dukić G.; Dukić, D. A study of computer literacy among Croatian students as support in planning the higher education development. // Tehnicki vjesnikTechnical Gazette. 19, 4(2012), pp. 735-742.

[18] Crnjac Milic, D.; Martinovic, G.; Fercec, I. Analysis of desirable changes in engineering education in the context of university education reform. // Tehnicki vjesnik-Technical Gazette. 14, (3, 4)(2007), pp. 31-36.

\section{Authors' addresses}

Assist. Prof. Ljubiša Preradović, PhD

University of Banja Luka

Faculty of Architecture, Civil Engineering and Geodesy

Stepe Stepanovića 77/III, 78000 Banja Luka, B\&H

E-mail: ljpreradovic@agfbl.org

\section{Sandra Kosić-Jeremić, PhD}

University of Banja Luka

Faculty of Architecture, Civil Engineering and Geodesy Stepe Stepanovića 77/III, 78000 Banja Luka, B\&H

E-mail: skosic@agfbl.org 